DOI https://doi.org/10.30525/978-9934-26-000-1-34

\title{
PROBLEMS OF MASS COMMUNICATION IN THE UKRAINIAN INFORMATION SPACE
}

\author{
Fisenko T. V. \\ Candidate of Sciences in Social Communications, \\ Associate professor at the Department of Publishing and Editing \\ National Technical University of Ukraine \\ «Igor Sikorsky Kyiv Polytechnic Institute» \\ Kyiv, Ukraine
}

The phenomenon of modern mass communications is associated with objective socio-political changes taking place in Ukraine. The main vectors, influencing trends in mass communications, are the complex nature, psychological and philosophical principles of communication policy, socio-cultural contexts, organizational and production component of media, the influence of politicians and foreign media policy of other countries (including Russia and the European Union).

The global tendency to increase mass communication flows contributes to the fact that the Ukrainian media space has now become a field not for the claimed realization of opinions pluralism as one of the main principles of democratic journalism, but an influential instrument of an engaged political actors (including foreign ones).

Thus, the modern psychological and philosophical principles of Ukrainian social communications are directly dependent not only on domestic political events in the country, but also have a significant factor of influence in the form of foreign relations with other countries. The latter can significantly affect, in particular, the country's image in the international arena (for example, the language conflict with Hungary as a pretext for xenophobic accusations of the Ukrainian executive), worsen the chances of potential EU membership, destroy trade and other relations with Ukraine.

The peculiarity of modern Ukrainian mass communications is their functioning in a destabilized society, which, on the one hand, simplifies work with the audience, on the other - largely depends on the level of its trust in various sources of information. Therefore, it should be taken into account while solving different types of communication tasks.

Modern mass communication processes are also described by the term "hybrid warfare". In fact, the concept of hybrid warfare and related communication strategies is actively developing in the American scientific school $[1 ; 2]$, and denote the mechanisms, methods and tactics of conflict against the enemy. The term does not mean the war itself as a state, but how it is conducted. Some researchers note that under the hybrid warfare model war 
functions in different operating environments, has synchronous effects on multiple battlefields, and is characterized by asymmetric tactics and techniques [3]. This statement also applies to the communicative aspect of the study of hybrid warfare, so it needs to be further developed and clarified.

In Ukrainian science, hybrid warfare as a component of political communication is considered from the standpoint of various sciences, in particular, political science, economics and sociology. The communicative component of hybrid aggression is researched in the works of E. Magda (for example, "Hybrid war: to survive and win" [4]). Given the environment of confrontation and information confrontation, the problems of the study of political communication in the Ukrainian and foreign media space require special attention.

To reveal the current trends of the Ukrainian information space the list of popular search queries for 2019-2020 was concluded using Google Trends and Infostream. It differs significantly from the results obtained in our previous study in 2016-2017 [5, p. 92]. A method of obtained data generalization has been used in the research. It allows identifying several blocks of the most interesting topics for the audience. At the same time, they are destabilizing and potentially critical, as they provoke the most violent and contradictory reactions in the Internet media and social networks. These blocks of topics can be divided into the following:

1. COVID-19 coronavirus pandemic.

2. Ukrainian authorities.

3. Economic situation in Ukraine.

4. Business problems in Ukraine.

5. World politics.

6. The War in Donbass

7. International policy towards Ukraine.

8. The energy of Ukraine.

9. Crises in the social sphere.

10. Reforms in the country.

In different periods, attention to these topics is distributed unevenly. Yes, some topics tend to be seasonal. For example, the energy issue is exacerbated during the heating season, the rise in prices of certain food groups - due to objective changes in the seasons, and so on. Other topics can be referred to as "extinct" - they are mentioned from time to time, in connection with some high-profile events, such as the violation of the regime of silence in the antiterrorist operation, exposing bribes to officials, and so on. Another group of topics escalates from time to time, chaotically or thoughtfully. For example, before the local council elections, a large number of candidates created artificial publicities, showing videos of their political advertisements with a humorous or senseless script (Oleg Lyashko, Iryna Vereshchuk). 
While covering the country's topical issues on the Internet, we can trace the use of numerous communicative techniques to influence public opinion. Let's outline the most common of them.

1. "Growing" the public opinion leaders ("agents of influence"). These can be well-known journalists and bloggers, or newly created characters who appear on the pages of media and social networks with their thoughts about current events and problems. By replicating content (for example, reposting), the audience gets the false impression that "everyone thinks so." A striking example of such a leader is Anatoly Shariy.

2. Spreading rumors and gossipi. They are especially popular due to the taste exclusivity of the information provided - for example, when it comes to restrictions due to a pandemic. The Rebuttal of rumors does not give a significant result, because in mass communications the effect of primacy plays a significant role. For example, rumors about the new lockdown in Ukraine due to the second wave of coronavirus disease received a similar response.

3. "60/40" method, the invention of which is attributed to J. Goebbels. It consists in creating media that provide $60 \%$ of their information allegedly in the interests of the enemy. Having thus earned his trust, the other $40 \%$ use it to implement extremely effective misinformation. Experts believe that the Ukrainian branch of "Vesti" (newspapers, website and radio) works on this principle.

Outlining the vectors of modern political communication will allow to develop a program of counteraction at the mass communication level, which will help to lay the groundwork for further positive changes during the country's exit from the crisis.

\section{References:}

1. Fleming B. P. The Hybrid Threat Concept: Contemporary War, Military Planning and the Advent of Unrestricted Operational Art: monograph. Kansas, 2011. 85 p.

2. Reeves S. R. The New Griffin of War: Hybrid International Armed Conflicts. Questia. URL: https://www.questia.com/library/journal/1G1316203914/the-new-griffin-of-war-hybrid-international-armed (accessed 05 November 2020).

3. Deep A. Hybrid War: Old Concept, New Techniques [Electronic resource] / A. Deep // Small Wars Journal. URL: http:// smallwarsjournal.com/jrnl/art/hybrid-war-old-concept-new-techniques (accessed 05 November 2020).

4. Magda E. Hybrid war: to survive and win. Kharkiv, 2015. 304 p.

5. Smola, L., Lytvyn, A., Mahda, E., Fisenko, T. Political counseling as a phenomenon of mass communications. Kharkiv, 2017. 200 p. 